\title{
Pemanfaatan Lingkungan sebagai Sumber Belajar terhadap Hasil Belajar IPS Kelas VII SMP Negeri 2 Ambarawa
}

\author{
Annisa Nur Fitriani, Arif Purnomo, Asep Ginanjar ${ }^{\bowtie}$ \\ Social Science Education Department, Faculty of Social Science, Universitas Negeri Semarang, \\ Indonesia
}

\section{Info Artikel}

Sejarah Artikel:

Disubmit:

Direvisi:

Diterima:

Keywords:

social science, environment learning resource

\begin{abstract}
Abstrak
Penelitian ini bertujuan untuk mengetahui pengaruh pemanfaatan lingkungan sebagai sumber belajar terhadap hasil belajar IPS Kelas VII di SMP Negeri 2 Ambarawa. Metode yang digunakan adalah penelitian kuantitatif dengan pendekatan quasi eksperimen. Lokasi penelitian ini berada di SMP Negeri 2 Ambarawa. Sampel yang digunakan yaitu kelas VII F sebagai kelas kontrol dan kelas VII G sebagai kelas eksperimen. Pengumpulan data menggunakan tes, observasi, dan dokumentasi. Guna menguji keabsahan data digunakan uji validitas dan reliabilitas juga mengukur daya beda serta tingkat kesukaran soal. Analisis data yang digunakan adalah uji normalitas, uji homogenitas dan uji paired sample t-test. Hasil penelitian menunjukkan bahwa pemanfaatan sumber belajar lingkungan pada mata pelajaran IPS Kelas VII di SMP Negeri 2 Ambarawa memilki pengaruh terhadap hasil belajar. Fakta ini di dapat setelah melihat nilai rata-rata kelas eksperimen pada saat post-test mengalami kenaikan yang semula 60 naik menjadi 76,5 atau apabila dihitung dengan presentase naik sebesar $27,5 \%$.
\end{abstract}

\begin{abstract}
This research was aims to know about the effect of the utilization of environment as a learning resource on social science learning achievement of $7^{\text {th }}$ grade in State Junior High School 2 Ambarawa. The method used was quantitative with quasi-experimental design. This research located in State Junior High School 2 Ambarawa. Sample are students from F class as a control class and students from $G$ class as an experimental class. The data was acquired via test, observation and documentation. In order to proof the validity of the data was used validity test, reliability test, level of difficulty and level of the differentiation. The data were analyzed by using normality test, homogeneity test also paired sample t-test. The results of the research showed that the utilization of environment as a learning resource on $7^{\text {th }}$ grade in State Junior High School 2 Ambarawa has affected the social science learning achievement. This fact was obtained after seeing the average of the experimental class at post-test which increase from 60 to 76.6 or $27.5 \%$ in percentage.
\end{abstract}

(C) 2019 Universitas Negeri Semarang

\footnotetext{
Alamat korespondensi:

Gedung C1 Lantai 1 FIS Unnes

Kampus Sekaran, Gunungpati, Semarang, 50229

E-mail: jurnalsosioliumpips@mail.unnes.ac.id
}

E-ISSN 2685-4929 


\section{PENDAHULUAN}

Bagi peserta didik, belajar pada dasarnya untuk memperoleh pengetahuan, keterampilan, dan sikap di mana saja, kapan saja, dan dengan apa saja, sebab sumber belajar terdapat di mana saja dan ada beragam jenisnya. Dengan terjadinya interaksi antara proses belajar kualitas interaksi peserta didik dengan sumber belajar berpengaruh sekali terhadap hasil belajar. Maka, dengan demikian ada perbedaan yang sangat besar antara peserta didik yang memiliki intensitas tinggi dalam pemanfaatan sumber belajar dengan peserta didik yang memiliki intensitas rendah dalam pemanfatan sumber belajar rendah dalam meraih hasil belajarnya (Abdullah, 2012:217).

Pada dasarnya belajar merupakan interaksi antar individu dengan lingkungannya. Belajar pada hakikatnya adalah interaksi antara individu dengan lingkungannya (Hamalik, 2008:194).

Keberadaan lingkungan sekitar peserta didik yang mendukung proses pembelajaran sangat menguntungkan bagi peserta didik untuk memanfaatkannya sebagai media dan sumber belajar. Sumber belajar adalah segala sesuatu yang dapat memberikan kemudahan kepada peserta didik dalam memperoleh sejumlah informasi, pengetahuan, pengalaman, dan keterampilan, dalam proses belajar mengajar (Mulyasa,2006:48).

Dengan memanfaatkan lingkungan sekitar sebagai sumber belajar, maka diharapkan dapat membantu dalam peningkatan mutu pembelajaran siswa dalam proses pembelajaran.

Selama proses pembelajaran guru belum memberdayakan potensi dirinya secara optimal. Pembelajaran yang dilakukan dengan ceramah dan siswa hanya diberikan fotokopi soal-soal untuk dikerjakan sebagai latihan tanpa memahami konsep secara mendalam. Hal ini menyebabkan siswa, kurang terlatih untuk menemukan, mengembangkan sendiri fakta dan konsep dari materi pelajaran dan mengaplikasikan konsep-konsep yang telah dipelajari dalam kehidupan nyata sehingga kemampuan berpikir kritis siswa kurang berkembang dengan baik. Beberapa siswa dalam mengikuti pelajaran belum sepenuhnya mampu mencerna pembelajaran karena dalam prosesnya penyampaian guru masih cenderung teacher centered. Proses pembelajaran kurang diminiati karena proses penyampaian yang monoton, materi pelajaran yang tidak dikemas secara apik, baik dari segi metode maupun media pembelajaran, pada saat sesi tanya jawabpun tidak banyak siswa yang mau bertanya pada proses pembelajaran, siswa kurang berani mengemukakan pendapatnya, dan tidak ada reward dari guru yang mengajar.

Dari uraian dalam latar belakang diatas maka dapat dirumuskan permasalahan sebagai berikut: (1) Bagaimanakah pemanfaatan lingkungan sebagai sumber belajar IPS Kelas VII di SMP Negeri 2 Ambarawa? (2) Bagaimana hasil belajar IPS Kelas VII di SMP Negeri 2 Ambarawa? (3) Bagaimana pengaruh pemanfaatan lingkungan sebagai sumber belajar terhadap hasil belajar IPS Kelas VII di SMP Negeri 2 Ambarawa?

Selain dengan permasalahan yang telah dirumuskan maka penelitian ini bertujuan untuk mendeskripsikan: (1) Mengetahui tentang pemanfaatan lingkungan sebagai sumber belajar IPS Kelas VII di SMP Negeri 2 Ambarawa, (2) Mengetahui tentang hasil belajar IPS Kelas VII di SMP Negeri 2 Ambarawa, (3) Mengetahui pengaruh pemanfaatan lingkungan sebagai sumber belajar terhadap hasil belajar IPS Kelas VII di SMP Negeri 2 Ambarawa.

\section{METODE}

Populasi dalam penelitian ini adalah sebanyak 210 siswa dari kelas VII A hingga kelas VII G SMP Negeri 2 Ambarawa. Sampel yang diambil dari populasi menggunakan teknik purposive sampling. Purposive sampling adalah teknik pengambilan data dengan pertimbangan tertentu (Sugiyono, 2012:218). Kriteria yang digunakan dalam menentukan sampel pada penelitian ini adalah: (1) Siswa yang terdapat pada populasi berasal dari tingkat yang sama yaitu berada pada tingkat kelas yang sama kelas VII SMP Negeri 2 Ambarawa, (2) Seluruh 
populasi memperoleh materi pelajaran IPS berdasarkan kurikulum yang sama, (3) Siswa diampu oleh guru yang sama, (4) Siswa diajarkan dengan jumlah jam pelajaran yang sama, (4) Buku yang digunakan sama, (5) Ratarata hasil belajar yang diperoleh juga relatif sama. Berdasarkan pertimbangan kriteriakriteria diatas maka dipilihlah kelas VII $F$ sebagai kelas kontrol dan kelas VII G sebagai kelas eksperimen.

Penelitian ini menggunakan uji normalitas membuktikan asumsi bahwa data berdistribusi normal. Pengujian ini menggunakan taraf signifikansi 0,05. Data dinyatakan berdistribusi normal jika nilai signifikansi lebih dari $0,05 . \mathrm{H}_{0}$ diterima apabila Sig $>\alpha$ (alpha) dengan interval kepercayaan yaitu 95\% sehingga $\alpha$ (alpha) $=5 \%=0,05$.

Uji homogenitas digunakan untuk mengetahui varian dari berbagai populasi sama atau tidak. Uji ini biasanya dilakukan sebagai prasyarat dalam analisis Independent Sample $T$ Test dan ANOVA. Dasar pengambilan keputusan dalam uji homogenitas adalah : jika signifikansi $<0,05$, maka dikatakan bahwa varian dari dua atau lebih kelompok populasi data adalah tidak sama. Jika nilai signifikansi > dari 0,05 maka, dikatakan bahwa varian dari dua atau lebih kelompok populasi data adalah sama.

Uji statistik yang digunakan dalam penelitian ini adalah uji statistik parametrik yaitu uji Paired - Sample T Test. Penggunan uji statistik parametrik karena sampel yang digunakan berasal dari populasi dengan distribusi normal. Uji ini digunakan untuk mengambil keputusan apakah hipotesis diterima atau ditolak. Kriteria pengambilan keputusan adalah: $\mathrm{H}_{0}$ diterima jika $\mathrm{t}$ hitung $<\mathrm{t}$ tabel pada : $5 \%$ dan $\mathrm{H}_{0}$ ditolak jika $\mathrm{t}$ hitung $>\mathrm{t}$ tabel pada $\alpha: 5 \%$

\section{HASIL DAN PEMBAHASAN}

\section{Uji Normalitas}

Hasil penelitian uji normalitas data pretest dan post-test sebagai berikut.
Tabel 1. Uji Normalitas Awal

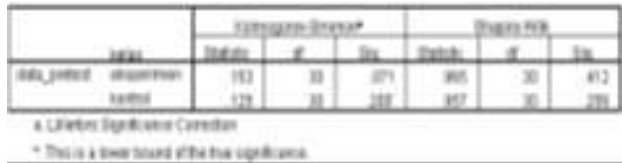

Sumber: Penelitian, 2018

Data dinyatakan berdistribusi normal jika nilai signifikansi lebih dari $0,05 . \mathrm{H}_{0}$ diterima apabila Sig $>\boldsymbol{\alpha}$ (alpha) dengan interval kepercayaan yaitu $95 \%$ sehingga $\alpha$ (alpha) $=5 \%$ $=0,05$.

Tabel 2. Uji Normalitas Akhir

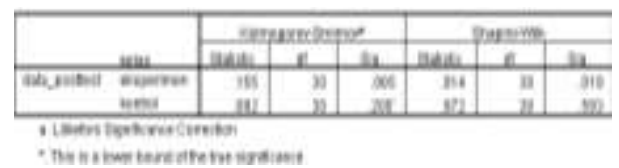

Sumber: Penelitian, 2018

Berdasarkan dapat disimpulkan bahwa dari hasil uji normalitas ini $\mathrm{H}_{0}$ diterima karena nilai Sig lebih besar dari nilai $\boldsymbol{\alpha}$ (alpha). Dengan hal ini baik kelas eksperimen maupun kelas kontrol memiliki data berdistribusi normal.

\section{Uji Homogenitas}

Hasil penelitian uji normalitas data pre-test dan post-test sebagai berikut.

Tabel 3. Uji Homogenitas Awal

\begin{tabular}{|} 
HasilBelaiarlPS \\
\begin{tabular}{|r|r|r|c|}
\hline $\begin{array}{c}\text { Levene } \\
\text { Statistic }\end{array}$ & df1 & \multicolumn{1}{c|}{ df2 } & \multicolumn{1}{c|}{ Siq. } \\
\hline .728 & 1 & 58 & .397 \\
\hline
\end{tabular}
\end{tabular}

Sumber: Penelitian, 2018

Dasar pengambilan keputusan dalam uji homogenitas adalah : jika signifikansi $<0,05$, maka dikatakan bahwa varian dari dua atau lebih kelompok populasi data adalah tidak sama. Jika nilai signifikansi > dari 0,05 maka, dikatakan bahwa varian dari dua atau lebih kelompok populasi data adalah sama

Tabel 4. Uji Homogenitas Akhir

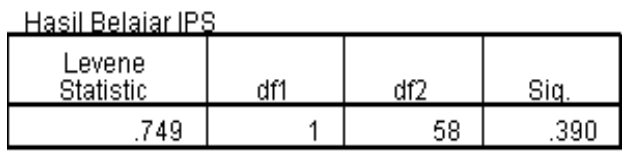

Sumber: Penelitian, 2018 
Berdasarkan uji homogenitas yang dilakukan dengan menggunakan $\mathrm{Uji}$ Levene tersebut maka data kedua kelas tersebut dinyatakan normal. Hal ini disebabkan nilai Sig lebih dari 0,05. Maka dengan hal ini dapat dinyatakan bahwa data yang diambil berasal dari sampel yang homogen.

\section{Uji Hipotesis}

Setelah uji normalitas dan homogenitas dilakukan, maka dapat digunakan uji hipotesis yakni uji Paired - Sample $T$ Test. Hasil uji tersebut ditunjukkan pada tabel berikut.

Tabel 5. Uji Homogenitas Awal

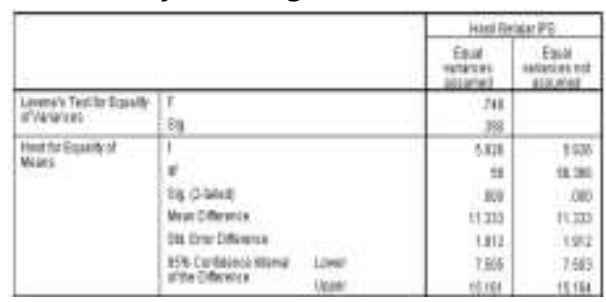

Sumber: Penelitian, 2018

Sesuai analisa data diatas maka $\mathrm{H}_{0}$ ditolak dan $\mathrm{H}_{\mathrm{a}}$ diterima dikarenakan $\mathrm{t}$ hitung $>\mathrm{t}$ tabel pada $\alpha: 5 \%$. besarnya pengaruh pemanfaatan lingkungan sebagai sumber belajar terhadap hasil belajar IPS Kelas VII SMP Negeri 2 Ambarawa pada materi pasar adalah $17,3 \%$.

\section{Hasil Belajar}

Hasil belajar yang diperoleh oleh kelas eksperimen akan disajikan pada tabel sebagai berikut.

Tabel 6 Hasil Belajar Kelas Eksperimen

\begin{tabular}{llll}
\hline \multirow{2}{*}{ Variasi } & \multicolumn{2}{c}{ Nilai } & Presentase \\
\cline { 2 - 3 } & Pre-test & Post-test & Kenaikan \\
\hline Rata- Rata & 60 & 76,5 & $27,5 \%$ \\
Nilai Terendah & 42,5 & 67,5 & $58,8 \%$ \\
Nilai Tertinggi & 75 & 90 & $20 \%$ \\
\hline
\end{tabular}

Sumber : Data Diolah 2018

Sesuai dengan apa yang ditampilkan pada tabel terjadi peningkatan hasil belajar di kelas eksperimen dari saat pre-test hingga post-test dimana presentase kenaikan yang dimiliki cukup tinggi. Sementara itu, hasil belajar yang diperoleh oleh kelas eksperimen akan disajikan pada tabel sebagai berikut.
Tabel 7 Hasil Belajar Kelas Kontrol

\begin{tabular}{llll}
\hline \multirow{2}{*}{ Variasi } & \multicolumn{2}{c}{ Nilai } & Presentase \\
\cline { 2 - 3 } & Pre-test & Post-test & $\begin{array}{c}\text { Ke } \\
\text { naikan }\end{array}$ \\
\hline Rata- Rata & 62 & 65,17 & $5,11 \%$ \\
Nilai Terendah & 47,5 & 50 & $5,26 \%$ \\
Nilai Tertinggi & 77,5 & 80 & $3,22 \%$ \\
\hline
\end{tabular}

Sumber : Data Diolah 2018

Sesuai dengan apa yang ditampilkan pada tabel dapat diketahui bahwa rata-rata hasil belajar kelas kontrol juga mengalami kenaikan meskipun tidak terlalu signifikan.

Berdasarkan hasil pengamatan peneliti penggunaan lingkungan sebagai sumber belajar pada materi pasar dapat mempercepat laju laju belajar dan membantu guru untuk menggunan waktu secara lebih baik, mengurangi beban guru dalam menyajikan informasi sehingga dapat lebih banyak membina dan mengembangkan semangat siswa untuk belajar, dan mengurangi kontrol guru yang kaku dan tradisonal. Selain itu, memberikan kesempatan kepada siswa untuk berkembang sesuai dengan kemampuannya, dapat menyampaikan informasi dan bahan secara lebih konkrit, dan mengurangi kesenjangan antara pembelajaran yang bersifat verbal dan abstrak dengan realitas yang sifatnya konkrit. Pembelajaran yang demikian terjadi dikarenakan pembelajaran berlangsung menarik, sehingga siswa akan mendapat contoh nyata dari lokasi survey serta gambar dari hasil dokumentasi siswa yang lain. Jadi, selama proses pembelajaran berlangsung, siswa terlibat aktif, siswa mencari tahu apa yang sebenernya terjadi di pasar dikaitkan dengan teori yang mereka dapatkan di kelas.

\section{SIMPULAN}

Berdasarkan hasil dan pembahasan di atas, maka penelitian ini dapat disimpulkan sebagai berikut: (1) Pemanfaatan lingkungan pada mata pelajaran IPS materi pelajaran Pasar Kelas VII di SMP Negeri 2 Ambarawa dapat dijadikan sebagai sumber belajar. Hal ini dikarenakan terjadinya peningkatan rata-rata kelas baik kelas kontrol maupun kelas 
eksperimen. (2) Hasil belajar IPS Kelas VII di SMP Negeri 2 Ambarawa pada materi pasar mengalami kenaikan baik kelas kontrol maupun eksperimen. Hal ini dapat dibuktikan dengan naiknya nilai rata-rata kelas yang di dapat saat pre-test maupun post-test. Rata-rata kelas yang di peroleh kelas kontrol adalah 62 dan kelas eksperimen 60 pada saat pre-test. Sedangkan, pada saat post-test nilai rata-rata kelas kontrol naik menjadi 65,17 dan kelas eksperimen naik menjadi 76,5. (3) Pemanfaatan sumber belajar lingkungan pada mata pelajaran IPS materi pelajaran Pasar Kelas VII di SMP Negeri 2 Ambarawa memilki pengaruh terhadap hasil belajar. Fakta ini di dapat setelah melihat nilai rata-rata kelas eksperimen pada saat post-test mengalami kenaikan yang semula 60 naik menjadi 76,5 atau apabila dihitung dengan presentase naik sebesar 27,5\%.

Saran yang dapat disumbangkan berkaitan dengan penelitian ini adalah sebagai berikut. (1) Dalam pembelajaran IPS diharapkan agar guru dapat lebih variatif dalam memanfaatkan sumber belajar hal ini perlu dilakukan supaya siswatidak mudah jenuh dengan cara guru mengajar. (2) Guru juga diharapkan dapat memanfaatkan sumber belajar yang terdekat karena dengan cara tersebut akan mempermudah guru dalam proses pembelajaran IPS, sehingga pembelajaran IPS dapat tercapai.

\section{DAFTAR PUSTAKA}

Abdullah, Ramli. 2012. 'Pembelajaran Berbasis Sumber Belajar'. Jurnal Ilmiah DIDAKTIKA Februari 2012 VOL. XII NO. 2, Hal. 216-231

Hamalik, Umar. 2001. Kurikulum dan Pembelajaran. Jakarta: Bumi Aksara

Mulyasa, E. 2006. Kurikulum Tingkat Satuan Pendidikan; Sebuah Panduan Praktis. Bandung : PT Remaja Rosdakarya

Sugiyono. 2012. Statistika Untuk Penelitian. Bandung: Alfabeta. 